E3S Web of Conferences 1, 10007 (2013)

DOI: $10.1051 / \mathrm{e} 3 \operatorname{sconf} / 20130110007$

(c) Owned by the authors, published by EDP Sciences, 2013

\title{
The concentrations of trace metals in plants from phosphogypsum waste heap in Wiślinka, northern Poland
}

\author{
A. Boryło ${ }^{1}$, W. Nowicki ${ }^{1}$, B. Skwarzec ${ }^{1}$ and $\underline{\text { G. Olszewski }}{ }^{1}$ \\ ${ }^{1}$ University of Gdańsk, Faculty of Chemistry, Sobieskiego 18, Gdańsk, Poland, aborylo@chem.univ.gda.pl
}

\begin{abstract}
The aim of this work was determination of trace metals ( $\mathrm{Pb}, \mathrm{Zn}, \mathrm{Ni}, \mathrm{Cu}$ and $\mathrm{Fe}$ ) in different plants collected in the vicinity of phosphogypsum waste heap in Wiślinka (northern Poland). The concentrations of trace metals were determined by two methods: AAS (atomic absorption spectrometry) and OES-ICP (atomic emission spectrometry with inductively coupled plasma). Enhanced levels of iron were observed in all the analyzed samples. This fact can be explained by the higher content of iron in the groundwaters of Żuławy Wiślane, where concentration of iron was $60 \mathrm{mg} / \mathrm{l}$. The trace metals concentrations in plant samples from phosphogypsum waste heap recorded in this study are generally higher than in control sites. In this study the relationship is shown between atmospheric trace metals deposition and elevated trace metals element concentrations in plants and topsoils, especially in the vicinity of phoshpogypsum waste heap.
\end{abstract}

Keywords: trace metals, plants, phosphogypsum waste heap, Wiślink (northern Poland)

\section{Introduction}

Trace metals may be defined as metals occuring at 1000 $\mu \mathrm{g} \mathrm{g}^{-1}$ or less in the earth' s crust and may be classified as heavy or light with respect to density. Trace heavy metals have densities greater than $5 \mathrm{~g} \mathrm{~cm}^{-3}$ whereas light metals less than $5 \mathrm{~g} \mathrm{~cm}^{-3}$ (Duffus, 1980; Osuji and Onjuke, 2004). We can divide them into four groups: elements of a very high degree of potential threat to the environment (Cd, Hg, Zn, Pb, Cr, Ag, Au, Sb, Sn, Tl), elements with a high degree of potential threat to the environment ( $\mathrm{Mn}$, $\mathrm{Fe}, \mathrm{Se}, \mathrm{Mo}$ ), elements of moderate potential threat to the environment $(\mathrm{Ni}, \mathrm{Co}, \mathrm{V})$, and elements with a low degree of potential threat to the environment $(\mathrm{Zr}, \mathrm{Ta}, \mathrm{Nb}, \mathrm{La})$ (PIOŚ, 1995). Trace metals in the environment are the result of natural geochemical processes, as well as of numerous anthropogenic sources (Allowey and Ayres, 1999). To the natural geochemical processes belong: weathering of rocks, evaporation of the oceans, volcanic eruptions, forest fires and soil processes (PIOŚ, 1995). The anthropogenic sources include mining and smelting of metal ores, agricultural materials (fertilizers and waste used for fertilizing, food preservatives, waste from intensive farming); energy based on burning coal and lignite, metallurgy, electronics, waste disposal and chemical industry (Allowey and Ayres, 1999). The natural content of heavy metals in the environment is very differentiated, because of the large diversity of properties of environmental media (air, soil, plants, or water) (Wolak et al, 1995). Content excess of heavy metals in plants can be negative on their development. In contaminated areas bodies of plants produced adaptation and defense mechanisms which involves precipitation of excess metal in crystalline forms or salt deposition on the tips of the leaves. This effect can explain improper size and form of plants in comparison with those grown on uncontaminated areas (Kabata-Pendias and Pendias, 1993).

\section{Materials and Methods}

The crop and meadow plant samples were collected from a private household I and II, which were situated at a distance of a 900 and 400 meters from the phosphogypsum waste in Wiślinka (northern Poland), respectively, in April 2009 and 2010 (Fig. 1). For comparison the same crop and meadow plants were collected in Osiek. The analyzed plants were separated into green parts and root. Obtained results of trace metals concentration in analyzed plants are given as an average of three experiments conducted for each sample. The concentrations of trace metals ( $\mathrm{Fe}, \mathrm{Pb}, \mathrm{Ni}, \mathrm{Zn}, \mathrm{Cu}$ ) were determined by two methods: AAS (atomic absorption spectrometry) and OES-ICP (atomic emission spectrometry with inductively coupled plasma). The detection limit for all analyzed trace metals was 0.005 $\mathrm{mg} \mathrm{L}^{-1}$. 


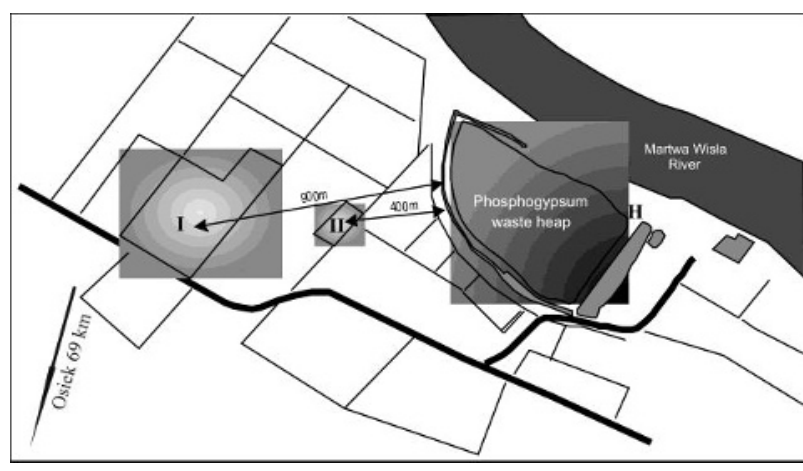

Fig.1 The places of analyzed plants samples collected

\section{Results and Discussion}

The obtained results of trace metals in crop and meadow plant samples are given in Tables 1-3. The uptake of metals concentrations by roots depends on speciation of metals and soil characteristic and type of plants species. Atmospheric metals are deposited on plant surfaces by rain and dust, too (Srinivas et al., 2009). The lead contents in analyzed crop plants vary from $1.9 \mathrm{~d}$. wt. $\mu \mathrm{g} \mathrm{g}^{-1}$ to $29.4 \mu \mathrm{g} \mathrm{g}^{-1} \mathrm{~d}$. wt. for green parts and from 13.7 d. wt. $\mu \mathrm{g} \mathrm{g}^{-1}$ to $77.0 \mu \mathrm{g} \mathrm{g}^{-1} \mathrm{~d}$. wt. for root. The values of zinc concentrations in analyzed plants were between 33.8-89.8 $\mu \mathrm{g} \mathrm{g}^{-1} \mathrm{~d}$. wt. in green parts and between $43.5-$ $185.5 \mu \mathrm{g} \mathrm{g}^{-1} \mathrm{~d}$. wt. in root. Nickel concentrations in analyzed samples range from $4 \mu \mathrm{g} \mathrm{g}^{-1}$ to $28.2 \mu \mathrm{g} \mathrm{g}^{-1}$ d. wt. in green parts and from $2.8 \mu \mathrm{g} \mathrm{g}^{-1}$ d.wt. to 57.4 $\mu \mathrm{g} \mathrm{g}^{-1} \mathrm{~d}$. wt. in root. Copper concentration in green parts of cultivated plants ranged between $0.5 \mu \mathrm{g} \mathrm{g}^{-1} \mathrm{~d}$.wt. and $27.5 \mu \mathrm{g} \mathrm{g}^{-1}$ d.wt., while values in root were between 2.8 $\mu \mathrm{g} \mathrm{g}^{-1}$ d.wt. and $107.0 \mu \mathrm{g} \mathrm{g}^{-1}$ d.wt. The iron concentrations in cultivated plants are between $75.8 \mu \mathrm{g} \mathrm{g}^{-}$ ${ }^{1}$ d.wt. and $568.4 \mu \mathrm{g} \mathrm{g}^{-1} \mathrm{~d}$.wt. for green parts and between $476.5 \mu \mathrm{g} \mathrm{g}^{-1}$ d.wt. and $897.4 \mu \mathrm{g} \mathrm{g}^{-1}$ d.wt. for root (Tab. 1). The remarkable high trace metals concentrations in root of analyzed samples may be related to kind of root. The higher concentrations were estimated in storage root system than fibrous root system. The diverse structures of analyzed plant roots (elongated taproots for garden radish and red beet, taproot system for carrot and parsley (Mowszowicz, 1986; Szafer et al., 1953), fibrous root systems for garden lettuce, onion, and leek) fundamentally influence the intake amounts of trace metals forms (Boryło and Skwarzec, 2011). The data stated that the transfer of trace metals into plants via roots is higher than transfer from atmospheric fallout. The leaves of vegetables such as red beet, garden radish and onion shows the highest concentrations of trace metals, because their leaves are most exposed part of plant to the environmental pollution due to the their large surface areas. Among meadow plants the highest contents of trace metals were noticed for plants which were collected in the vicinity of phosphogypsum waste heap.

The lowest trace metals contents were calculated for weeds, which were collected from uncontaminated area.Moreover, the highest trace metals concentrations were estimated for iron in root of plants (between 437.5 $\mu \mathrm{g} \mathrm{g}^{-1}$ d.wt. and $6642.9 \mu \mathrm{g} \mathrm{g}^{-1}$ d.wt.), the lowest for copper (between $22.5 \mu \mathrm{g} \mathrm{g}^{-1}$ d.wt. and $59.1 \mu \mathrm{g} \mathrm{g}^{-1}$ d.wt.)
(Tab. 2 and 3). Among green parts of analyzed meadow plants the highest contents of trace metals were measured for iron, too (between $420.6 \mu \mathrm{g} \mathrm{g}^{-1} \mathrm{~d}$.wt. and $657.0 \mu \mathrm{g} \mathrm{g}$ ${ }^{1} \mathrm{~d}$. wt. ), the lowest for nickel (between $35.3 \mu \mathrm{g} \mathrm{g}^{-1} \mathrm{~d}$.wt. and $83.8 \mu \mathrm{g} \mathrm{g}^{-1}$ d. wt.) (Tab. 2 and 3). The higher concentrations of trace metals were observed in root and green parts for Potentilla anserina in comparison to Taraxacum officinal, although Taraxacum officinal is used in the investigation of trace metals pollution. The higher content of trace metals in silverweed (Potentilla anserina) is probably associated with the silvery hairy character of leaves as opposed to the shiny and smooth character of dandelion leaves. These hairy surfaces could adsorb higher concentrations of trace metals from fallout unlike the smooth surface of leaves (Boryło and Skwarzec, 2011). Among the weeds the concentrations of trace metals were differences. Generally, the higher contents of trace metals in green parts were measured for $\mathrm{Ni}$ and $\mathrm{Cu}$, but in roots of analyzed plants were estimated higher concentrations of $\mathrm{Pb}, \mathrm{Fe}$ and $\mathrm{Zn}$. The results shows that the vegetables and weeds studied appears to be rich in iron, too. The amount of metal accumulated by a plant is species-dependent and refers decisively to its morphological structure (Chiarenzelli et al., 2001, Rosamilia et al., 2004). The numerous studies show the increase of metal content in plants samples in the surroundings of contaminated areas (smelters, steelworks, power stations, mining sites or mixed industrial centres) (Boryło et al, 2011; Jeran et al, 1995). On the basis of values of trace metals concentrations in edible plants from phosphogypsum waste zone and uncontaminated area from Osiek, it was calculated that contaminations of vegetables from private household are much higher, varied considerable and range from 2.1 for $\mathrm{Pb}, 3.7$ for $\mathrm{Zn}$, 2.8 for $\mathrm{Ni}$ and 3.2 for $\mathrm{Fe}$ in green parts to 11.8 for $\mathrm{Pb}$, 12.2 for $\mathrm{Zn}, 9.4$ for $\mathrm{Ni}$ and 5.5 for $\mathrm{Fe}$ in root times higher in comparison to non-contaminated vegetables (control samples). Much higher concentrations of heavy metals in the samples of analyzed crops and grassland, which were obtained in Wiślinka compared to values measured in uncontaminated area indicate that another source of pollution is also the phosphogypsum waste heap.

\section{Conclusion}

In this study the trace metals concentration in plants samples was considered as a means to get insight into the pollution of environment around the phosphogypsum waste heap in Wiślinka (northern Poland). In the phosphogypsum waste heap area the trace metals were reported for all the plants samples in higher concentrations compared with control area. The content of trace elements in analyzed plants samples varied widely, depending upon the composition of the soil, which was enriched with phosphogypsum particles and other environmental factors, but the detailed mechanisms are still unknown. This study shows that industrial pollutions around phosphogypsum waste heap in Wiślinka are an important source of trace metals in crop and meadow plants. The analyzed cultivated plants from Wiślinka area may provide larger amounts of trace metals to our body. 
Tab.1 Average trace metals concentration in crop plants collected in April 2009 from private household II and Osiek (*) $(\mathrm{n}=3)$

\begin{tabular}{|c|c|c|c|c|c|}
\hline \multirow[t]{2}{*}{ Samples } & $\mathrm{Pb}$ & $\mathrm{Zn}$ & $\mathrm{Ni}$ & $\mathrm{Cu}$ & $\mathrm{Fe}$ \\
\hline & \multicolumn{5}{|c|}{ [ $\mu \mathrm{g} \cdot \mathrm{g}^{-1}$ d.wt.] } \\
\hline carrot (green parts) & $12.4 \pm 9.0$ & $35.0 \pm 6.0$ & $5.9 \pm 0,8$ & $14.5 \pm 1,2$ & $375.5 \pm 6.2$ \\
\hline carrot (root) & $13.7 \pm 9.0$ & b.d.l. & $57.4 \pm 3.7$ & $89.6 \pm 5.1$ & $546.0 \pm 7.8$ \\
\hline parsley (green parts) & $1.9 \pm 0.1$ & $35.8 \pm 6.0$ & $2.9 \pm 2.1$ & $15.1 \pm 3.3$ & $580.8 \pm 6.4$ \\
\hline parsley (root) & $14.1 \pm 8.0$ & $43.5 \pm 7.1$ & $2.8 \pm 2.0$ & $2.8 \pm 0.6$ & $897.4 \pm 19.1$ \\
\hline red beet (green parts) & $19.8 \pm 12.0$ & $60.4 \pm 4.6$ & $9.4 \pm 0.6$ & $18.1 \pm 0.5$ & $346.2 \pm 7.3$ \\
\hline red beet (root) & $77.0 \pm 9.6$ & $185.5 \pm 16.5$ & $48.5 \pm 5.1$ & $107.0 \pm 7.9$ & $476.5 \pm 3.5$ \\
\hline onion (green parts) & $29.4 \pm 12.8$ & $66.0 \pm 32.6$ & $28.2 \pm 3.3$ & $27.5 \pm 3.8$ & $568.4 \pm 28.3$ \\
\hline onion (root) & $56.9 \pm 29.1$ & $133.1 \pm 19.1$ & $51.3 \pm 5.3$ & $71.8 \pm 1.9$ & $761.9 \pm 9.5$ \\
\hline leek (green parts) & $11.2 \pm 8.3$ & $33.8 \pm 5.8$ & $4.0 \pm 1.1$ & $9.6 \pm 0.4$ & $116.1 \pm 2.5$ \\
\hline leek (root) & $38.1 \pm 7.7$ & $56.1 \pm 10.1$ & $9.7 \pm 1.0$ & b.d.l. & $420.3 \pm 2.6$ \\
\hline garden radish (green parts) & b.d.l. & $57.7 \pm 30.6$ & b.d.1. & b.d.l. & $75.8 \pm 16.3$ \\
\hline garden radish (root) & $73.0 \pm 6.4$ & $78.2 \pm 4.3$ & $16.7 \pm 1.4$ & b.d.l. & $199.7 \pm 3.5$ \\
\hline garden lettuce (green parts) & $27.9 \pm 2.8$ & $89.8 \pm 6.0$ & $15.0 \pm 0.4$ & $0.5 \pm 0.1$ & $341.4 \pm 3.9$ \\
\hline garden lettuce (root) & b.d.l. & $177.1 \pm 10.8$ & b.d.l. & b.d.l. & $777.1 \pm 9.8$ \\
\hline carrot (green parts)* & $14.9 \pm 2.6$ & $33.0 \pm 0.1$ & $5.0 \pm 1.2$ & b.d.1. & $153.8 \pm 4.5$ \\
\hline carrot (root)* & $4.9 \pm 1.2$ & $23.5 \pm 3.0$ & $7.7 \pm 1.2$ & b.d.l. & $62.1 \pm 2.2$ \\
\hline parsley (green parts)* & $12.0 \pm 8.8$ & $33.4 \pm 3.9$ & $4.7 \pm 0.9$ & b.d.l. & $262.5 \pm 7.4$ \\
\hline parsley (root)* & b.d.l. & b.d.l. & b.d.l. & b.d.1. & $60.3 \pm 2.7$ \\
\hline onion (green part)* & $13.1 \pm 5.6$ & b.d.l. & $8.2 \pm 2.1$ & b.d.l. & $130.8 \pm 3.3$ \\
\hline onion (root)* & $6.0 \pm 3.1$ & $10.1 \pm 5.4$ & $4.9 \pm 0.6$ & b.d.l. & $69.4 \pm 1.9$ \\
\hline garden lettuce (green parts)* & $9.9 \pm 4.5$ & $36.5 \pm 4.3$ & $5.8 \pm 1.8$ & b.d.l. & $208.3 \pm 3.1$ \\
\hline garden lettuce (root)* & $12.2 \pm 4.6$ & $21.7 \pm 3.6$ & $7.2 \pm 1.0$ & b.d.l. & $544.3 \pm 5.7$ \\
\hline
\end{tabular}

b.d.l. - below the detection limit; $\mathrm{n}$ - number of individuals

Tab.2 Average trace metals concentration in Taraxacum officinale samples collected in April 2009 from the area around the phosphogypsum waste heap and Osiek $(n=3)$

\begin{tabular}{lccccc}
\hline Samples & $\mathrm{Pb}$ & $\mathrm{Zn}$ & $\mathrm{Ni}$ & $\mathrm{Cu}$ & $\mathrm{Fe}$ \\
\cline { 2 - 6 } & \multicolumn{3}{c}{$\left[\mu \mathrm{g} \cdot \mathrm{g}^{-1}\right.$ d.wt.] } \\
\hline green parts $(*)$ & $174.5 \pm 30.4$ & $69.1 \pm 19.1$ & $35.3 \pm 2.5$ & $38.2 \pm 2.5$ & $420.6 \pm 7.4$ \\
root $(*)$ & $204.4 \pm 29.5$ & $133.7 \pm 20.8$ & $56.9 \pm 10.9$ & $52.5 \pm 3.5$ & $477.0 \pm 5.8$ \\
green parts $(* *)$ & $416.1 \pm 28.8$ & $330.4 \pm 7.4$ & $83.8 \pm 14.9$ & $90.8 \pm 4.0$ & $546.1 \pm 13.4$ \\
root $(* *)$ & $108.8 \pm 28.9$ & $1888.6 \pm 29.8$ & $53.2 \pm 5.5$ & $22.5 \pm 1.7$ & $437.5 \pm 13.2$ \\
green parts $(*)$ & $36.0 \pm 5.2$ & $86.0 \pm 2.6$ & b.d.l. & b.d.l. & $527.5 \pm 13.0$ \\
root $(*)$ & $39.2 \pm 3.3$ & $84.5 \pm 1.2$ & b.d.l. & b.d.l. & $1080.7 \pm 26.8$ \\
green parts $(* * *)$ & b.d.1. & $89.9 \pm 21.2$ & b.d.l. & $35.9 \pm 4.3$ & $107.7 \pm 8.2$ \\
root $(* * *)$ & b.d.1. & $111.6 \pm 3.2$ & b.d.l. & $64.2 \pm 2.8$ & $424.8 \pm 7.6$ \\
\hline
\end{tabular}

$(*)$ private household $\mathrm{I},(* *)$ area around retention reservoir, $(* * *)$ control plant, b.d.l. - below the detection limit; $\mathrm{n}-$ number of individuals

Tab.3 Average trace metals concentration in Potentilla anserina samples collected in April 2009 from the area around the phosphogypsum waste heap and Osiek $(n=3)$

\begin{tabular}{|c|c|c|c|c|c|}
\hline \multirow[t]{2}{*}{ Samples } & $\mathrm{Pb}$ & $\mathrm{Zn}$ & $\mathrm{Ni}$ & $\mathrm{Cu}$ & $\mathrm{Fe}$ \\
\hline & \multicolumn{5}{|c|}{$\left[\mu \mathrm{g} \cdot \mathrm{g}^{-1}\right.$ d.wt. $]$} \\
\hline green parts $(*)$ & $186.0 \pm 30.0$ & $637.3 \pm 23.1$ & $88.6 \pm 6.9$ & $206.2 \pm 3.0$ & $627.9 \pm 11.8$ \\
\hline $\operatorname{root}(*)$ & $185.6 \pm 22.3$ & $86.7 \pm 14.1$ & $58.1 \pm 4.8$ & $42.2 \pm 1.9$ & $2903.1 \pm 42.2$ \\
\hline green parts $(* *)$ & $158.0 \pm 14.3$ & $523.1 \pm 24.6$ & $66.4 \pm 3.9$ & $165.4 \pm 3.4$ & $657.0 \pm 12.3$ \\
\hline $\operatorname{root}(* *)$ & $398.7 \pm 32.5$ & $207.4 \pm 13.1$ & $79.5 \pm 7.8$ & $59.1 \pm 1.9$ & $6642.9 \pm 79.0$ \\
\hline green parts $(*)$ & $27.3 \pm 8.1$ & $90.6 \pm 5.0$ & b.d.l. & b.d.l. & $639.2 \pm 7.4$ \\
\hline $\operatorname{root}(*)$ & $20.0 \pm 5.6$ & $53.6 \pm 3.5$ & b.d.l. & b.d.l. & $881.6 \pm 9.5$ \\
\hline green parts $(* * *)$ & $9.6 \pm 2.9$ & $60.2 \pm 2.6$ & b.d.1. & b.d.l. & $436.5 \pm 8.8$ \\
\hline $\operatorname{root}(* * *)$ & $27.1 \pm 8.1$ & $89.9 \pm 4.9$ & b.d.l. & b.d.l. & $639.8 \pm 7.4$ \\
\hline
\end{tabular}

$(*)$ private household I, $(* *)$ private household II, $(* * *)$ control plant, b.d.l. - below the detection limit; $\mathrm{n}$ - number of individuals 


\section{Acknowledgments}

The authors would like to thank the Ministry of Science and Higher Education for the financial support under grant DS/8120-4-0176-12.

\section{References}

Allowey BJ; Ayres DC. Chemiczne podstawy zanieczyszczenia środowiska. Warszawa: PWN,1999.

Boryło A, Skwarzec B. Bioaccumulation of polonium ${ }^{210} \mathrm{Po}$ and uranium $\left({ }^{234} \mathrm{U},{ }^{238} \mathrm{U}\right)$ in plants around phosphogypsum waste heap in Wislinka (northern Poland). Radiochim Acta 2011;99:1-13.

Boryło A, Skwarzec B, Olszewski G, Nowicki W. Wpływ składowiska fosfogipsów w Wiślince na środowisko (Część II). Ochrona Powietrza i Problemy Odpadów 2011;45:81-94.

Chiarenzelli JR, Aspler LB, Dunn C, Cousens B, Ozarko $\mathrm{D}$, Powis K. Multi-element and rare earth composition of lichens, mosses, and vascular plants for the Central Barrenlands, Nunavut, Canada. Appl Geochem 2001;16:245-270.

Duffus JH. Environmental Toxicology. Edward Arnold Publishers Limited, London, 1980.

Jeran Z, Byrne AR, Batić F. Transplanted epiphytic lichens as biomonitors of air contamination by natural radionuclides around the Žirowski Vrh
Urbanium mine, Slovenia. Lichenologist 1995;27(5):375-385.

Kabata-Pendias A, Pendias H. Biogeochemia pierwiastków śladowych. Warszawa:PWN; 1993.

Mowszowicz J. Flora jesienna. Przewodnik do oznaczania dziko rosnących jesiennych pospolitych roślin zielnych. Warszawa;1986.

Osuji LC, Onjuke ChM. Trace heavy metals associated with crude oil: A case study of Ebocha- 8 oil-spillpolluted site in Niger Delta, Nigeria. Chem Biodiver 2004;1:1708-1715.

Państwowa Inspekcja Ochrony Środowiska, Wojewódzki Inspektorat Ochrony Środowiska w Chełmie, Uniwersytet Marii Curie-Skłodowskiej w Lublinie. Metale ciężkie w środowisku i ich analiza. Chełm: Biblioteka Monitoringu Środowiska;1995.

Rosamilia S, Gaudino S, Sansone U, Belli M, Jeran Z, Ruisi S, Zucconi L. Uranium isotopes, metals and other elements in lichens and tree barks collected in Bosnia-Herzegovina. $\mathbf{J}$ of Atmosp Chem 2004;49:447-460.

Srinivas N, Ramakrishna Rao S, Suresh Kumar S. Trace metal accumulation in vegetables grown in industrial and semi-urban areas - a case study. Appl Ecol and Environ Research 2009;7(2):131-139.

Szafer W, Kulczyński S. Rośliny polskie. Warszawa: PWN;1953.

Wolak W, Leboda R, Hudnicki Z. Metale ciężkie w środowisku i ich analiza. Chełm: Wydawnictwo Polskiego Inspektoratu Ochrony Środowiska;1995. 